\title{
Horse Seminal Plasma proteins (HSP-1 and HSP-2) concentration: a possible marker for poor fertility?
}

\author{
Luisa A. D. Garcia, Enio L. R. Brito, Priscila Serpa, Joana Gregory, Claudio Natalini, Rodrigo C. Mattos and Maria Inês M. Jobim
}

Faculdade de Veterinária - Equinos, Universidade Federal do Rio Grande do Sul, Porto Alegre, Brazil

\begin{abstract}
Summary: Seminal plasma (SP) proteins have been assessed in relation to reproductive fertility levels or infertility, in several species of mammals, particularly domestic animals. Horse seminal plasma proteins 1 (HSP-1) and 2 (HSP-2) are the most abundant proteins in equine seminal plasma. The aim of this study was to investigate in adult stallions the concentrations of seminal plasma HSP-1/2 and total protein in the breeding season and non-breeding season and to determine if these concentrations were related with fertility. Seminal plasma was obtained from 42 ejaculates of 11 adult stallions (3-25 yrs). Stallions were allocated into two groups (good and poor fertility) according to pregnancy rates of mares, and to their semen viability data in the first collection day. Seminal plasma HSP-1/2 concentrations (mg/mL) were measured and analyzed by an Ultra High Performance Liquid Cromatography using a UHPLC column. There were significant differences $(P<0.05)$ in total protein and $\mathrm{HSPl} / 2$ concentration $(\mathrm{mg} / \mathrm{mL}$, mean $\pm \mathrm{SD})$ in the ejaculates from good and poor fertility stallions. The HSP1/2 concentration did not show differences in the first and second ejaculates of good fertility stallions in both the non-breeding and breeding season. Seminal plasma of stallions classified as poor fertility showed significant difference $(\mathrm{P}<0.05)$ in HSP-1/2 concentration between the first and second ejaculate in both the non-breeding and breeding season. In conclusion, the concentration of the major proteins of stallion seminal plasma HSP1/2 was higher in ejaculates from stallions with poor fertility, is not influenced by the season and could serve as biomarker for poor fertility in stallions.
\end{abstract}

Keywords: stallion / UHPLC / breeding season / seminal plasma / reproduction

Ist die Konzentration der Sperma-Plasmaproteine HSP-1 und HSP-2 des Pferdes ein möglicher Marker für mangelhafte Fruchtbarkeit?

Die Proteine des Seminalplasmas wurden im Zusammenhang mit dem Fruchtbarkeits- oder Unfruchtbarkeitslevel diverser Säugetiere, speziell der Haustiere, bewertet. Die "Horse Seminal Plasma" Proteine 1 (HSP-1) und 2 (HSP-2) sind die am meisten vorkommenden Proteine im Seminalplasma von Pferden. Ziel der Studie war es, die Konzentration des Seminalplasmas HSP-1/2 und die gesamten Proteine bei erwachsenen Hengsten, während und außerhalb der Decksaison zu untersuchen und festzustellen, ob diese Konzentrationen mit der Fruchtbarkeit zusammenhängen. Seminalplasma wurden aus 42 Ejakulaten von 11 erwachsenen Hengsten (3-25 Jahre) gewonnen. Die Hengste wurden in zwei Gruppen aufgeteilt (hohe und niedrige Fruchtbarkeit) gemäß der Trächtigkeitsrate der Stuten und der Viabilität des Samens in der Samenentnahme des ersten Tages. Samenplasma wurde aus 42 Ejakulaten gewonnen und die Konzentration von HSP-1/2 (mg/mL) wurden mit einer Hochleistungsflüssigkeitschromatographie unter Anwendungen einer UHPLC Trennsäule gemessen und analysiert. Es wurden signifikante Unterschiede $(\mathrm{P}<0.05)$ in der Konzentration der gesamten und der HSP1/2 Proteine $(\mathrm{mg} / \mathrm{mL}$, Durchschnitt \pm SD) im Ejakulat der Hengste mit hohen und niedrigen Fruchtbarkeit festgestellt. Die HSP $\backslash 2$ Konzentration der Hengste mit hoher Fertilität zeigte keinen Unterschied im ersten und zweiten Ejakulat sowohl während als auch außerhalb der Decksaison. Seminalplasma, der mit niedriger Fertilität eingestuften Hengste, zeigten einen signifikanten Unterschied $(P<0.05)$ zwischen dem ersten und zweiten Ejakulat sowohl innerhalb als auch außerhalb der Decksaison. Abschließend wurde festgestellt, dass die HPS1/2 Konzentration, die am häufigsten vorkommende Proteine, höher im Ejakulat der Hengste mit niedriger Fertilität war, diese nicht durch die Saison beeinflusst wurde und kann als Biomarker geringer Fertilität eingesetzt werden.

Schlüsselwörter: Hengst / UHPLC / Decksaison / Seminalplasma / Reproduktion

Citation: L. A. D. Garcia, E. L. R. Brito, P. Serpa, J. Gregory, C Natalini, R. C. Mattos, M. I. M. Jobim (2014) Horse Seminal Plasma proteins (HSP-1 and HSP-2) concentration: a possible marker for poor fertility? Pferdeheilkunde 30, 557-560

Correspondence: Maria Inês Mascarenhas Jobim, PPGMA,Faculdade de Veterinária, Universidade Federal do Rio Grande do Sul, Av. Paulo Gama 110 - Bairro Farroupilha -90010-460 Porto Alegre, Brazil, E-mail: Inês.jobim@ufrgs.br

\section{Introduction}

Progress has been made in developing reliable indicators of ejaculate quality that allow exclusion of low-quality ejaculates for use in natural breeding or artificial insemination. Physical semen characteristics and sperm morphology measurements allow detection of the stallions most likely to be fertile. However, some of them are or became subfertile despite acceptable results of the conventional breeding soundness examination (Barrier-Battut et al. 2005). The ability to select these fertile stallions or predict fertility using biomarkers is a promising goal. Accurate or predictive genetic and protein markers are still needed.
The suggested functions of seminal plasma proteins include their involvement in several essential steps preceding fertilization, such as regulating sperm capacitation, establishment of the oviductal sperm reservoir, modulation of the uterine immune response and sperm transport in the female genital tract, as well as in gamete interaction and fusion (TöpferPetersen et al. 2005).

Seminal plasma (SP) proteins have been assessed in relation to reproductive fertility levels or infertility, in several species of mammals, particularly domestic animals. SP proteins have been identified as associated with high and low fertility in bulls (Killian et al. 1993) isolated as osteopontin (OPN) and 
lipocalin-type prostaglandin D synthase respectively (Cancel et al. 1997, Gerena et al. 1998). The latter has been always present in the sperm-rich fraction of ejaculates in species with fractionated ejaculation. OPN has been related to fertility in pigs (Hao et al. 2006, Hao et al. 2008) and stallions (Brandon et al. 1999). Jobim et al. (2005) observed one protein $(20-25 \mathrm{kDa}$, pl 8.5-8.7) present only in the ejaculates of high fertility stallions and another protein $(25-30 \mathrm{kDa}$, pl 7.5-7.7) that had higher relative protein content in ejaculates of low fertility stallions. More recently, the abundance of cysteine-rich secretory protein 3 (CRISP3) was positively related to first cycle conception rate and the abundance of four seminal plasma proteins were identified as being negatively related to fertility; these were identified as kallikrein-1E2 (KLK2), clusterin, and seminal plasma proteins 1 (SP1) and 2 (SP2) (Novak et al. 2010).

Horse seminal plasma proteins 1 (HSP-1) and 2 (HSP-2); recently, renamed SP-1 and SP-2, respectively are the most abundant proteins in equine seminal plasma, accounting for 70-80\% of the total proteins (Calvete et al. 1994). They showed heparin-binding ability (Calvete et al. 1994) and were found to be associated to the sperm surface, indicating a potential role in fertilization (Töpfer-Petersen et al. 2005). They belong to the short seminal Fn-2 type proteins (Calvete et al. 1995 and Ekhlasi-Hundrieser et al. 2005) and are the equine orthologs to the major bovine heparin-binding proteins (BSP), which have been shown to be involved in early fertilization steps (capacitation).

The season of the year influences many of the physical and chemical characteristics of stallion semen as well as fertility (Pickett et al. 1975). The influence of season on the total protein concentration and the composition of seminal plasma of many species has been described in the ram (Perez-Pé et al. 2001, Cardozo et al. 2006), boar (Trudeau et al. 1986, Strzezek 2002) and horse (Janett et al. 2003), with significant differences between breeding and non-breeding seasons.

The aim of this study was to investigate in adult stallions the concentrations of seminal plasma HSP-1/2 and total protein in the breeding season and non-breeding season and to determine if these concentrations were related with fertility.

\section{Material and methods}

Animals and Samples Collection

Seminal plasma was obtained from 11 adult stallions (325yrs) from commercial herds in the State of Rio Grande do

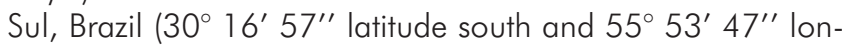
gitude west at 145 meters above sea level). Data were collected during the non-breeding season (winter and spring months) and the breeding season (summer months). Stallions were maintained under similar handling and feeding conditions, kept free in pastures. They were allocated into two groups (good and poor fertility; Giesecke et al. 2010) according to pregnancy rates of mares assessed by veterinary and to their semen viability data in the first collection day. Stallions of good fertility $(n=6)$ had a minimum of $65 \%$ of pregnancy rates during the 2 -year period and more than $1.5 \times 10^{9}$ viable sperm. Stallions classified as poor fertility $(n=5)$ had no more than $55 \%$ of pregnancy rates and less than $1.4 \times 10^{9}$ viable sperm. Sperm viability (SV) was calculated using the following formula: SV = progressive sperm motility * morphologically normal sperm ${ }^{*}$ sperm concentration.

Two ejaculates were collected by artificial vagina from each stallion in the breeding season and non-breeding season with one hour of interval. One of the poor fertility stallion die during the experiment and was not collected in the breeding season. A total of 42 ejaculates from 11 stallions were used. After collection and analysis, a $2.0 \mathrm{~mL}$ aliquot of semen was centrifuged at $1,500 \times \mathrm{g}$ for 15 to $20 \mathrm{~min}$ to obtain seminal plasma. The supernatant seminal plasma was transferred to cryovials for storage in liquid nitrogen and subsequent laboratory analysis. Frozen samples were thawed, recentrifuged at $10,000 \times \mathrm{g}$ for $60 \mathrm{~min}$ at $4^{\circ} \mathrm{C}$ and $50 \mu \mathrm{L}$ were taken from the supernatant and transferred to cryovials for storage at $-80^{\circ} \mathrm{C}$.

\section{Semen Collection and Evaluation}

After collection, gel-free semen was taken to evaluate for volume, sperm motility, sperm concentration, and percent of morphologically normal sperm, according to conventional semen analysis described by Sieme et al. (2001).

\section{Total Protein Concentration}

Protein concentration in seminal plasma from each sample was assessed according to the method described by Lowry et al. (1951), using bovine serum albumin $(1 \mathrm{mg} / \mathrm{mL})$ as a standard.

\section{HSP-1/2 Concentrations}

Seminal plasma HSP-1/2 concentrations $(\mathrm{mg} / \mathrm{mL}$ ) were measured according to the method described by Calvete et al. (1997) with modification (trifluoroacetic acid was replaced by trichloroacetic acid as one of the mobile phases for chromatography analyses). The samples were defrosted at room temperature, filtered in $0.22 \mu \mathrm{m}$ filters (Biofil Syringe Filter) and analyzed by an Ultra High Performance Liquid Cromatography using a Thermo Fisher Scientific UHPLC column (Hypersil Gold AX $50 \times 2.1 \mathrm{~mm}, 1.9$ micron pore) eluted at $1 \mathrm{~mL} / \mathrm{min}$ with a gradient of $0.1 \%(\mathrm{v} / \mathrm{v})$ trichloroacetic acid in $(\mathrm{A})$ water and (B) acetonitrile as follows: isocratically with $25 \% \mathrm{~B}$ for 5 min, followed by $25-30 \%$ B for $5 \mathrm{~min}$, and $30-70 \%$ B for $160 \mathrm{~min}$. Proteins were detected at $220 \mathrm{~nm}$. Integration of the sample curves with the calibration curve was done with ChromQuest ${ }^{\circledR}$ and values for the HSP-1/2 protein concentration were attained. The calibration curve was obtained with HSP-1/2 purificated kindly provided by Dr. J. J. Calvete (Instituto de Biomedicina de Valencia, Spain).

\section{Statistical analysis}

Data were analyzed using Statistical Analysis Software $\left(\mathrm{SAS}^{\circledR}\right)$. Analysis of variance (GLM-General Linear Model) was performed to compare (among fertility groups) the HSP-1/2 and total protein concentration in the first and second ejaculate from 
good and poor fertility stallions measured in the non-breeding and breeding season. The Tukey post hoc test was used to locate differences and $\mathrm{P}<0.05$ was regarded as significant.

\section{Results}

Overall pregnancy rates ranged from $66-100 \%$ in stallions of good fertility and from $0-53 \%$ in stallions of poor fertility. In two samples from the good fertility group and in one sample from the poor fertility group HSP1/2 detection was not possible. HSP-1/2 ( $n=39$ ejaculates) and total protein concentration ( $n=42$ ejaculates) (mean $\pm S D$ ) from stallion with good and poor fertility are shown in Figure 1. There were differences $(\mathrm{P}<0.05)$ in total protein and $\mathrm{HSP} 1 / 2$ concentration $(\mathrm{mg} / \mathrm{mL}$, mean $\pm \mathrm{SD})$ in the ejaculates from good and poor fertility stallions. HSP-1/2 accounting for $80 \%$ of the total proteins in the samples of stallions of good fertility, while that HSP-1/2 accounting for $93 \%$ of the total proteins in stallions classified as poor fertility. Results of HSP-1/2 concentration $(\mathrm{mg} / \mathrm{mL}$, mean $\pm \mathrm{SD})$ in the first and second ejaculate from good and poor fertility stallions measured in the non-breeding and breeding season are shown in Table 1. There were no differences $(P>0.05)$ in HSP-1/2 concentration among adult stallion ages (3-25yrs).

\section{Discussion}

As a part of the fertilization process, seminal plasma proteins play an important role in sperm reservoir formation, sperm capacitation, and sperm-oocyte interactions (Foxcroft et al. 2008, Rodríguez-Martínez et al. 2008). Specific seminal plasma proteins have previously been identified as potential mar-

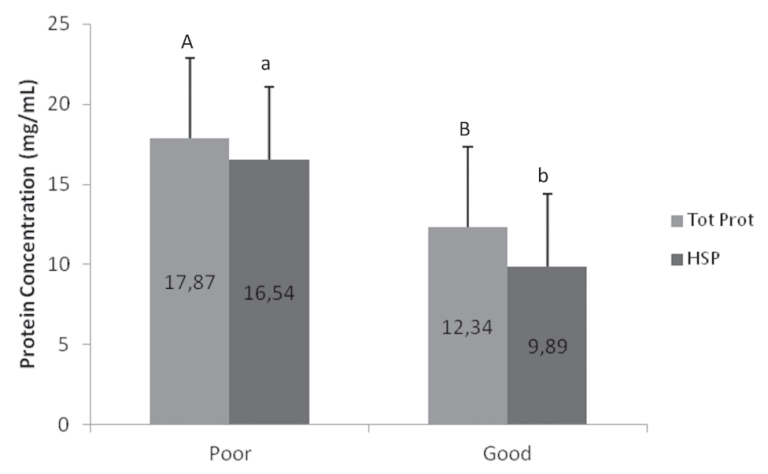

Fig. 1 HSP-1/2 ( $n=39$ ejaculates) and total protein $(n=42$ ejaculates) concentration (mean \pm SD) from stallion with good and poor fertility. Different superscripts indicate differences $(P<0.05)$. kers of male fertility in the bull (Killian et al. 1993) and stallion (Brandon et al. 1999, Novak et al. 2010). The present study investigated seminal plasma HSP-1/2 concentration to determine if these concentrations are related with stallion fertility in vivo, providing the basis to use them as a complementary tool to identify sires with high and low relative fertility that could have a considerable impact on reproductive efficiency.

The highest values of HSP-1/2 concentration were found in the ejaculates from stallions with poor fertility in the non-breeding and breeding season. This is consistent with previous findings of Novak et al. (2010) in the breeding season. HSP-1/2 shares significant homology with PDC-109 (Calvete et al. 1995) and this protein at higher concentrations induces membrane permeabilisation (Gasset et al. 1997), stimulates cholesterol and phosphatidylcholine efflux (Therien et al. 1999), and also acts in the perturbation of the membrane integrity (Calvete et al. 2007). Perhaps the greater amount of HSP-1/2 in seminal plasma, as detected in samples from stallions with poor fertility, had the same negative effect as PDC109 above mentioned. HSP-1/2 exhibits chaperone-like activity and may protect other proteins of equine seminal plasma against misfolding, unfolding or aggregation (Sankhal et al. 2012). The structure of HSP- $1 / 2$ is largely unordered and it is likely that this structural plasticity helps it to interact with other seminal plasma proteins effectively and protect them under stress conditions. Probably the values observed in the poor fertility stallions were related with a stress condition with production of other proteins that stimulates the high concentration of HSP-1/2.

Additionally, the proteins $\mathrm{HSPl} / 2$ were hypothesized to be similar to a sperm motility inhibitor protein (SPMI, 18-22 $\mathrm{kDa}$ ) originating from the seminal vesicles (Brandon et al. 1999). The HSP-1/2 comprised $80 \%$ of the total proteins in the samples of stallions of good fertility which agree with the results of Calvete et al. (1994) that observed two major proteins, the heparin-binding HSP-1 and HSP-2, accounted for $70-80 \%$ of the total seminal plasma protein. However an increase in HSP-1/2 concentration was observed in samples of seminal plasma of stallions classified as poor fertility. The findings of Calvete et al. (1994) come only from healthy reproductively active stallions while in this study were used stallions of good and poor fertility. Total protein concentration showed the same pattern found for HSP-1/2 concentration because these proteins together account for $70-80 \%$ of the total proteins in stallion seminal plasma (Calvete et al. 1994).

The HSP $1 / 2$ show higher concentration in the ejaculates from stallions in the poor fertility group, in the first and second eja-

\begin{tabular}{|c|c|c|c|c|}
\hline \multirow[t]{2}{*}{ Fertility } & \multicolumn{2}{|c|}{ non-breeding } & \multicolumn{2}{|c|}{ breeding } \\
\hline & \multicolumn{4}{|c|}{ Ejaculates } \\
\hline & 1 & 2 & 1 & 2 \\
\hline Good & $\begin{aligned} 10.97 & \pm 1.19^{A a} \\
n & =6\end{aligned}$ & $\begin{array}{c}8.31 \pm 0.82^{A a} \\
n=6\end{array}$ & $\begin{aligned} 10.98 & \pm 1.81^{\mathrm{Aa}} \\
\mathrm{n} & =5\end{aligned}$ & $\begin{array}{c}9.40 \pm 2.04^{\mathrm{Aa}} \\
n=5\end{array}$ \\
\hline Poor & $\begin{aligned} 19.99 & \pm 1.21^{\mathrm{Ba}} \\
\mathrm{n} & =5\end{aligned}$ & $\begin{aligned} 13.51 & \pm 0.79^{\mathrm{Bb}} \\
\mathrm{n} & =4\end{aligned}$ & $\begin{aligned} 23.99 & \pm 1.80^{B a} \\
n & =4\end{aligned}$ & $\begin{aligned} 13.77 & \pm 1.33^{A b} \\
n & =4\end{aligned}$ \\
\hline
\end{tabular}

${ }^{A, B}$ Column values with different superscripts indicates significant difference $(P<0.05)$.

${ }^{a, b}$ Row values with different superscripts indicates significant difference $(P<0.05)$. 
culate in the non-breeding season and in the first ejaculate in the breeding season in comparison with the good fertility group. In contrast, the second ejaculate in breeding season not shown to vary between the fertility groups. Perhaps the increase in the ejaculations number of the stallions during the breeding season may have an effect in the amount of HSPI/2 without variation between fertility groups in the second ejaculate.

The HSPl/2 concentration did not show differences in the first and second ejaculates of good fertility stallions in both the nonbreeding and breeding season, indicating uniformity in their concentrations. On the other hand, HSP-1/2 concentration observed in samples of seminal plasma of stallions classified as poor fertility showed difference between the first and second ejaculate in both the non-breeding and breeding season.

In conclusion, the concentration of the major proteins of stallion seminal plasma HSP1/2 was higher in ejaculates from stallions with poor fertility, is not influenced by the season and could serve as biomarker for poor fertility in stallions.

\section{Acknowledgements}

The authors are grateful to Dr. Juan J. Calvete (Instituto de Biomedicina de Valencia, Valencia, Spain) for supply the HSP$1 / 2$ purified and to CNPq, CAPES and FAPERGS for funding this study.

\section{Conflict of interest}

None of the authors have any conflict of interest to declare.

\section{Animal welfare statement}

Statement 23850, Universidade Federal do Rio Grande do Sul, Porto Alegre, Brazil.

\section{References}

Barrier-Battut J. L., Dacheux J. L., Gatti P., Rouviere C., Stanciu F., Dacheux M. (2005) Seminal plasma proteins and semen characteristics in relation with fertility in stallions. Proceedings of the 4th International Symposium on Stallion Reproduction 89. Animal Reproduction Science. Issues 1-4, 255-258

Brandon C. I., Heusner G. L., Caudle A. B., Fayrer-Hosken R. A. (1999) Two-dimensional polyacrylamide gel electrophoresis of equine seminal plasma proteins and their correlation with fertility. Theriogenology 52, 863-873

Calvete J. J., Nessau S., Mann K., Sanz L., Sieme H., Klug E., TöpferPetersen E. (1994) Isolation and biochemical characterization of stallion seminal plasma proteins. Reprod. Domest. Anim. 29, 41 1-426

Calvete J. J., Mann K., Schafer W., Sanz L., Reinert M., Nessau S., Töpfer-Petersen E. (1995) Amino acid sequence of HSP-1, a major protein of stallion seminal plasma: effect of glycosylation on its heparin-and gelatin-binding capabilities. Biochem. J. 310, 615-622

Calvete J. J., Raida M., Gentzel M., Urbanke C., Sanz L., Töpfer-Petersen E. (1997) Isolation and characterization of heparin- and phosphorylcholine-binding proteins of boar and stallion seminal plasma. Primary structure of porcine pB1. FEBS Lett. 407, 201-206

Calvete J. J., Sanz L. (2007) Insights into structure-function correlations of ungulate seminal plasma proteins. Soc. Reprod. Fertil. Suppl. 65, 201-215
Cancel A. M., Chapman D. A., Killian G. J. (1997) Osteopontin is the 55-kilodalton fertility-associated protein in Holstein bull seminal plasma. Biol. Reprod. 57, 1293-1301

Cardozo J. A., Fernandez-Juan M. F., Forcada A., Abecia T., MuinoBlanco J. A., Cebrian-Perez J. A. (2006) Monthly variations in ovine seminal plasma proteins analyzed by two-dimensional polyacrylamide gel electrophoresis. Theriogenology. 66, 841-850

Ekhlasi-Hundrieser M., Schafer B., Kirchhoff C., Hess O., Bellair S., Muller P., Töpfer-Petersen E. (2005) Structural and molecular characterization of equine sperm-binding fibronectin-II module proteins. Mol. Reprod. Dev. 70, 45-57

Foxcroft G. R., Dyck M. K., Ruiz-Sanchez A., Novak S., Dixon W. T. (2008) Identifying useable semen. Theriogenology 70, 1324-1336

Gasset M, Saiz J. L., Laynez J., Sanz L., Gentzel M., Töpfer-Petersen E., Calvete J. J. (1997) Conformational features and thermal stability of bovine seminal plasma protein PDC-109 oligomers and phosphorylcholine-bound complexes. Eur. J. Biochem. 250, 735-744

Gerena R. L., Irikura D., Urade Y., Eguchi N., Chapman D. A., Killian G. J. (1998) Identification of a fertility-associated protein in bull seminal plasma as lipocalin-type prostaglandin D synthase. Biol. Reprod. 58, 826-833

Giesecke K., Hamann H., Sieme H., Distl O. (2010) INHBA-associated markers as candidates for stallion fertility. Reprod. Domest. Anim. 45, 342-347

Hao Y., Mathialagan N., Walters E., Mao J., Lai L., Becker D., Li W., Critser J., Prather R. S. (2006) Osteopontin reduces polyspermy during in vitro fertilization of porcine oocytes. Biol. Reprod. 75, 726-733

Hao Y., Murphy C. N., Spate L., Wax D., Zhong Z., Samuel M., Mathialagan N., Schatten H., Prather R. S. (2008) Osteopontin improves in vitro development of porcine embryos and decreases apoptosis. Mol. Reprod. Dev. 75, 291-298

Janett F., Thun R., Niederer K., Burger D., Hässig M. (2003) Seasonal changes in semen quality and freezability in the Warmblood Stallion. Theriogenology 60, 453-461

Jobim M. I. M., Bustamante Filho I. C., Trein C. R., Wald V. B., Gregory R. M., Mattos R. C. (2005) Equine seminal plasma proteins related with fertility. Anim. Reprod. Sci. 89, 305-308

Killian G. J., Chapman D. A., Rogowski L. A. (1993) Fertility-associated proteins in Holstein bull seminal plasma. Biol. Reprod. 49, 1202-1207

Lowry O. H., Rosebrough W. J., Farr A. L., Randall R. J. (1951) Protein measurement with folin phenol reagent. J. Biol. Chem. 193, 265-275

Novak S., Smith T. A., Paradis L., Burwash M. K., Ruiz-Sanchez A., Dyck M. K., Foxcroft G. R., Dixon W. T. (2010) Biomarkers of in vivo fertility in sperm and seminal plasma of fertile stallions Theriogenology 74, 956-967

Perez-Pe R., Barrios B., Muino-Blanco T., Cebrian-Perez J. A. (2001) Seasonal differences in ram seminal plasma revealed by partition in an aqueous two-phase system. J. Chromatogr. B. 760, 113-121

Pickett B. W., Faulkner L. C., Voss J. L. (1975) Effect of season on some characteristics stallion semen. J. Reprod. Fertil. 23, 25-28

Rodrıguez-Martınez H., Saravia F., Wallgren M., Roca J., Pena F. J. (2008) Influence of seminal plasma on the kinematics of boar spermatozoa during freezing. Theriogenology. 70, 1242-1250

Sankhala R. S., Kumar C. S., Singh B. P., Arangasamy A,, Swamy M. J. (2012). HSP-1/2, a major protein of equine seminal plasma, exhibits chaperone-like activity Biochemical and Biophysical Research Communications. 427, 18-23

Sieme H., Töpfer-Petersen E., Bader H., Petzoldt R., Merkt H. (2001) A.I.- sperm of the Stallion. Evaluation criteria and minimal standards - a survey. Pferdeheilkunde 17, 145-154

Strzezek J. (2002) Secretory activity of boar seminal vesicle glands. Reprod. Biol. 3, 243-266

Therien I., Moreau R., Manjunath P. (1999) Bovine seminal plasma phospholipid-binding proteins stimulate phospholipid efflux from epididymal sperm. Biol. Reprod. 59, 768-776

Töpfer-Petersen E., Ekhlasi-Hundrieser M., Kirchhoff C., Leeb T., Sieme H. (2005) The role of stallion seminal proteins in fertilization. Anim. Reprod. Sci. 89, 159-170

Trudeau V., Sanford L. M. (1986) Effect of season and social environment on testis size and semen quality of the adult Landrace boar. J. Anim. Sci. 63, 1211-1219 